\title{
Challenging Parties and
}

\section{Anti-Fascism in the Name of}

\author{
Democracy: The Fronte
}

\section{dell'Uomo Qualunque and its}

\section{Impact on Italy's Republic}

\section{PEPIJ C O R D U W E E R}

This article studies the political ideology of the Italian political movement Fronte dell'Uomo Qualunque in the light of the problems of party democracy in Italy. The movement existed only for a few years in the aftermath of the Second World War, but the impact of its ideology on post-war Italy was large. The article argues that the party's ideology should be studied beyond the anti-fascist-fascist divide and that it provides a window onto the contestation of party politics in republican Italy. It contextualises the movement in the political transition from fascism to republic and highlights key elements of the Front's ideology. The article then proceeds to demonstrate how the movement distinguished itself from the parties of the Italian resistance and advocated a radical break with the way in which the relationship between the Italian state and citizens had been practiced through subsequent regimes. The way in which the movement aimed to highlight the alleged similarities between the fascist and republican political order, and its own claim to democratic legitimacy, constitute a distinct political tradition which resurfaced in the political crisis of the 1990 .

\section{The Position of the Fronte dell'Uomo Qualunque in Italian History}

The Common Man's Front (Fronte dell'Uomo Qualunque; hereafter: Front), founded in Naples in the wake of the liberation of Italy from fascist rule, occupies a peculiar

P. Corduwener, Drift 6,35I2 BS Utrecht, the Netherlands, p.corduwener@uu.nl

An earlier version of this article was presented at the Council for European Studies Conference in Paris. Many thanks to Ido de Haan and Jan Willem Duyvendak for their comments on the paper given there. Special thanks goes to Giovanni Orsina for his excellent feedback on drafts of this article. I am also indebted to the anonymous reviewers of Contemporary European History for their insightful suggestions for improvement and to the Royal Netherlands Institute in Rome for facilitating my research in Italy. 
position in Italian history. On the one hand, its political impact was limited. In the elections for the constitutional assembly in 1946, the Front captured two million votes and even became the biggest party in Rome. Yet the party's support was restricted mainly to the south and the capital, and it was all but eliminated in the I948 general election. On the other hand, however, the Front's electoral surge, albeit brief, raises important questions about the way in which party democracy and antifascism established themselves as dominant principles within post-war Italy. Indeed, how could a party that claimed to be democratic but rejected the principles of party politics and anti-fascism establish itself in this moment of political transition? And what does this reveal about the history of post-war Italian democracy?

Perhaps as a result of these paradoxes, the Front still occupies a somewhat mysterious place in Italian historiography, in which two different perspectives can be discerned. A first perspective studies the history of the Front 'as a party' and sees the Front through the prism of the distinction between fascism and anti-fascism dominant at the time. This perspective investigates the Front's position on the fascist - anti-fascist continuum and explains the social bases of its support, which, as an antianti-fascist party, it drew for a substantial part from former fascists. ${ }^{1}$ Seen from this perspective, the Front has been identified as a deeply conservative force to which the Catholic Action, a conservative social movement controlled by the Vatican, looked to exert political influence. ${ }^{2}$ But the Front is also characterised as a party that the very least promoted a lack of confrontation with the fascist past, ${ }^{3}$ if not constituting a prelude to the neo-fascist Italian Social Movement. ${ }^{4}$ In any case, the Front is understood as the 'most passionate interpreter' of the 'wind of the South' (vento del $S u d$ ), because it represented those who had not experienced the resistance against fascism and Nazism in the north of the country and those for whom the establishment of anti-fascist values 'often generated preoccupations and fear'. ${ }^{5}$ Studied from this standpoint, the Front's historical relevance is limited largely to the transitional era from I943 to I948, and the geographical cleavages which this transition accentuated.

A second strand of scholarship studies the Front from a different angle. It aims to disentangle the Front from the fascist-anti-fascist divide and is concerned mainly with the history of the Front 'as an ideology'. ${ }^{6}$ By studying how the Front and its charismatic leader, the Neapolitan playwright Guglielmo Giannini, addressed

1 See, for example, A. M. Imbriani, Vento del Sud. Moderati, Reazionari, Qualunquisti 1943-1948 (Bologna: Il Mulino, I996); S. Setta, L’Uomo Qualunque 1944-1948 (Bari: Laterza, I975).

2 C. Masala, 'Die Democrazia Cristiana I943-I963. Zur Entwicklung des partito nazionale', in M. Gehler, W. Kaiser and H. Wohnout, eds., Christdemokratie in Europa in 2o. Jahrhundert (Vienna: Böhlau Verlag, 200I), 348-60, here 353 .

3 C. Duggan, 'Italy and the Cold War and the Legacy of Fascism', in C. Duggan and C. Wagstaff, eds., Italy and the Cold War: Politics, Culture, Society (Oxford: Berg, I995), I-24, here 7.

4 P. Ignazi, Il polo escluso. Profilo storico del Movimento Sociale Italiano (Bologna: Il Mulino, I989), 40-6.

5 Imbriani, Vento del Sud, 46, 54.

6 See, for example, G. Orsina, 'L'antipolitica dei moderati: dal qualunquismo al berlusconismo', Ventunesimo secolo, 30, I (20I3), 9I-III; E. Capozzi, 'La polemica antipartitocratica', in G. Orsina, ed., Storia delle destra nell'Italia repubblicana (Soveria Mannelli: Rubbettino editore, 2009), I79-206; G. Orsina, Il Berlusconismo nella storia d'Italia (Venice: Marsilo editore, 2013), translated as G. Orsina, Berlusconism and Italy. A Historical Interpretation (Basingstoke: Palgrave McMillan, 20I4). 
the ills of Italy's nascent democracy, the Front is considered an early expression of contestation of the 'republic of the parties' which was constructed in the aftermath of the war. Some scholars go even further and interpret the Front as the invention of 'anti-politics' in an age of mass democracy. ${ }^{7}$ The Front has been characterised as a populist movement, ${ }^{8}$ and Marco Tarchi even contends that the movement, with its 'fast and simple solutions' and its critique on the 'plutocrats' of political parties, was the 'prototype' of modern European populism. ${ }^{9}$ Seen from this perspective, the Front's relevance extends far beyond its limited electoral success in the aftermath of the Second World War, and the party provides a window onto the contestation of party democracy in post-war Italy, and, possibly, Europe at large.

This article builds upon the insights offered by this second perspective on the Front and is consequently especially concerned with the Front's political ideology. It explores the Front's political discourse through an analysis of its weekly newspaper in the period I945-I947, as well as the political pamphlet The Crowd. Six Thousand Years of Struggle Against Tyranny (La Folla. Seimila anni di lotta contro la tirannide, hereafter: La Folla), which Giannini wrote in I943-I944. ${ }^{10}$ In doing so it demonstrates that the Front's challenge to anti-fascism and party democracy reveals an underlying current of Italian history which has come to the surface at moments of political transition. The Front's rejection of political parties, the challenge it posed to the anti-fascist consensus and its claim to protect the people from domination by a political elite, constitute an Italian tradition in which a right-wing and an anti-system strand join. ${ }^{11}$ The Front's ideology thereby sheds light on the contestation of the 'republic of the parties' which determined Italy's history for four decades until it collapsed in the early I990s.

\section{The Ideology of the Front in Italy's Political Transition}

It has become something of a platitude to state that Italy's transition from fascism to democracy after the Second World War was particularly problematic because the major political parties had competing conceptions of democracy. ${ }^{12}$ After the

${ }^{7}$ See, in particular, C. M. Lomartire, Il Qualunquista. Guglielmo Giannini e l'antipolitica (Milan: Mondadori, 2008).

8 G. Pasquino, 'Political Development', in P. McCarthy, ed., Italy since 1945 (Oxford: Oxford University Press, 200I), 69-94, here 82.

9 M. Tarchi, 'Populismo a la Italiana', Historia Social, 46 (2003), 95-II2, here 96.

10 G. Giannini, La Folla. Sei, mila anni di lotta contro la tirannide (Rome, I945). The book was written between September I943 and June I944, after Giannini's son, to whom the book is dedicated, was killed in the War.

11 Orsina, 'L'antipolitica dei moderati'.

12 The literature on this topic is abundant: see, for example, R. A. Ventresca, From Fascism to Democracy. Culture and Politics in the Italian Election of 1948 (Toronto: Toronto University Press, 2004); S. Pons, L'impossibile egemonia. L'USSR, il PCI e le origine della guerra fredda, 1943-1947 (Rome: Carocci editore, I999); M. Forno, 1945. Italia tra fascismo e democrazia (Rome: Carocci editore, 2008); G. Scilanga, Le Due Italie dalla Resistenza alla Repubblica (Bari: Laterza, 20I0); F. Barbagallo, Dal '43 al '48. La formazione dell'Italia democratica (Turin: Einaudi, I996). 
liberation of Rome, the major political parties formed the Committee of National Liberation (Comitato di Liberazione Nazionale; hereafter: CLN) and subsequently a government of national unity which governed the liberated parts of the country and guided Italy's political transition. The Front spoke out vehemently against these collaborative efforts to 'democratise' Italy and did not cease to stress that these parties were similar to each other - and the fascist regime which had preceded them.

However, notwithstanding the Front's allegations of the 'sameness' of the political class, there were nascent, but growing, divisions among the parties of the antifascist resistance, most notably between Christian democrats and the Marxist left, concerning the question of what kind of 'democracy' post-fascist Italy should become. Christian Democracy (Democrazia Cristiana; DC), the successor of the Italian People's Party (Partito Popolare Italiano) which had been banned by Mussolini in I926, was motivated to make a new beginning for Catholic-inspired politics. ${ }^{13}$ Alcide de Gasperi, the party's leader, attacked the left and considered its conception of politics incompatible with the establishment of democracy in Italy. For the DC, individual liberties and checks and balances against a possible radicalisation of the masses were key components of postwar democracy. ${ }^{14}$ Democracy was 'anti-revolution', and De Gasperi held against the left that 'not a line of the writings of Lenin, Marx or Stalin has been repudiated.... But when it comes to laying the foundations of the democratic state, this silence cannot be enough. . . . According to our conceptions, no clubs, no Jacobinism, we want democracy in earnest'. ${ }^{15}$ Communist leader Palmiro Togliatti countered De Gasperi's allegations and aimed to establish the democratic credentials of his party, epitomised by his 'turn of Salerno' (Svolta di Salerno) in which the Italian Communist Party (Partito Comunista Italiano; hereafter: PCI) committed itself to defeating fascism in a government of national unity and muted its revolutionary pretensions. The PCI envisioned the development of a so-called 'progressive democracy' in Italy. This concept was rather vague but denoted at least greater social equality, commitment to a multi-party system and the eradication of all remnants of fascism. The party accepted the principles of parliamentary democracy while continuing to be tied closely to the Soviet Union. ${ }^{16}$

Despite these growing ideological divisions, the CLN parties shared a few core principles concerning Italy's democratic transition. First of all, as the Svolta di Salerno exemplified, they were united in their anti-fascism and in their conviction that Italy's democracy should be founded on this anti-fascism. Indeed, as historian Pietro

13 P. Scoppola, La democrazia cristiana in Italia dal 1943 al 1947 (Milan: Dott. A. Giuffrè Editore, I975), I $77-$ I 80 .

14 G. Campanini, 'I programmi del partito democratico cristiana', in F. Malgeri, ed., Storia della Democrazia cristiana. vol. 1 1943-1948. Le origini: La DC dalla resistenza alla repubblica (Rome: Edizione Cinque Lune, I987), 205-29.

15 A de Gasperi, 'Le basi dello stato democratico e la battaglia di domani' (I945), in Malgeri, ed., Storia della Democrazia Cristiana. vol. I, 463-9, here 466-8.

16 Agosti, 'Partito Nuovo e democrazia progressiva nell'elaborazione dei comunisti', in C. Fransceschini, S. Guerrieri and G. Monina, eds., Le idee costituzionali della resistenza. Atti del Convegno di studi Roma 19, 20 e 21 ottobre 1995 (Rome: Presidenza del Consiglio dei ministri, I995), 235-48; P. di Loreto, Togliatti e la "Doppiezza". Il PCI tra democrazia e insurrezione. 1944-1949 (Bologna: Il Mulino, I99I), 26. 
Scoppola concludes, 'Italian democracy could only be reborn as anti-fascist, because Italy had lived through and suffered from the fascist experience: anti-fascism is the natural and original historical connotation of Italian democracy'. ${ }^{17}$ Secondly, the resistance parties were all convinced that Italian citizens were in need of political education and subsequently displayed an aspiration to inculcate in them genuine democratic values'. ${ }^{18}$ Finally, they also shared the conviction that political parties were crucial in guiding the democratic development of the country and that parties could legitimately use the state in order to pursue these political objectives. ${ }^{19}$

Anti-fascism automatically gave democratic legitimacy to the government of national unity and, by extension, to the Italian post-war state which the resistance parties commenced to reconstruct. ${ }^{20}$ After the liberation of the entire peninsula in April 1945, resistance hero Ferruccio Parri was appointed prime minister, which symbolised the force of the 'wind of the North' (vento del Nord), the spirit of political renewal embodied by the resistance against fascism and Nazism which had matured in the centre and north of the country between 1943 and $1945 .{ }^{21}$ Another resistance hero and intellectual, Vittorio Foa, nonetheless warned that it was essential to reach out to forces beyond the resistance to prevent Italy from being divided in two and to take citizens in the south into account for whom the anti-fascist resistance had been a far less formative experience. ${ }^{22}$ The Front captured these feelings of resentment against the resistance parties and epitomised the 'wind of the South'. It represented those who had not experienced the Nazi occupation and the Italian resistance, who were traditionally sceptical about the possibilities to enact social change and who resented the 'political class' which imposed its values on the rest of the peninsula. ${ }^{23}$

The Front thereby aimed to question the equation between anti-fascism, political parties and democracy that the CLN parties, albeit in different ways, advocated. For Giannini, the most important distinction in politics was not that between fascism and anti-fascism, but between the 'masters' and the folla, the 'crowd' of ordinary and benign people. ${ }^{24}$ The character of the political regime and ideology to which political elites belonged was only of secondary importance, because in the end the ordinary people always suffered from their decisions. Seen from this perspective,

17 P. Scoppola, La Repubblica dei partiti. Evoluzione e crisi di un sistema politico (Bologna: Il Mulino, I997), I3I.

18 R. A. Ventresca, 'Mussolini's Ghost: Italy's Duce in History and Memory', History and Memory, I8, I (2006), 86-II9, here 9I.

19 M. S. Piretti, 'Continuità e rottura alla nascita del sistema dei partiti', in Fransceschini Guerrieri and Monina, eds., Le idee costituzionali della resistenza, 206-2I2.

${ }^{20}$ Ventresca, 'Mussolini's Ghost: Italy's Duce in History and Memory', 96.

21 Forno, I945. Italia tra fascismo e democrazia, 67.

${ }^{22}$ V. Foa, Lavori in corso 1943-1946 (Turin: Einaudi, I999), 2 I.

23 Imbriani, Vento del Sud, 56; S. Lupo, Partito e antipartito. Una storia politica della prima Repubblica, 1946-1978 (Roma: Donzelli Editore, 2004), 44; G. Orsina, 'Le virtù liberali del qualunquismo', in G. Giannini, La Folla. Seimila anni di lotta contro la tirannide. Con un dibattito su 'Liberalismo e qualunquismo' di Giovanni Orsina e Valerio Zanone (Soveria Mannelli: Rubbettino, 2002), 7-26, here 21.

${ }^{24}$ S. Setta, 'Postfazione: Guglielmo Giannini e il Movimento del Uomo Qualunque', in G. Giannini, La Folla. Seimila anni di lotta contro la tirannide. Con un dibattito su "Liberalismo e qualunquismo" di Giovanni Orsina e Valerio Zanone (Soveria Mannelli: Rubbettino, 2002), 224-9. 
Pietro Nenni, the socialist leader, for instance, was not truly different from the fascist leader, but 'instead, the same thing: Mister Nenni, Mister Mussolini ... they are all equally useless and harmful', Giannini stated. ${ }^{25}$ As a consequence of this rejection of the fascist-anti-fascist divide, the Front's political ideology distinguished itself from the major parties of the anti-fascist coalition in four ways.

Firstly, the Front had specifically liberal traits. ${ }^{26}$ Giannini's political pamphlet $\mathrm{La}$ Folla has even been described as having a 'clearly libertarian' and 'almost anarchistic' character'. ${ }^{27}$ The Front itself claimed to have 'the most liberal programme of all parties' ${ }^{28}$ It endorsed 'negative liberty' as it was above all in favour of a freedom from interference and restraints. The party was an advocate of a free market economy, which was remarkable in a period of broad consensus between left-wing parties and Christian democrats on the imperative of increased state interference in the economy. The Front, by contrast, was in favour of a liberal economic policy with little state interference, the reduced power of labour unions and the privatisation of state-owned companies. ${ }^{29}$ It even argued against the state playing a dominant role in providing employment, since this would have to be covered by tax payers' money which could instead be used for private investment.

Secondly, and inspired by its liberal view on the state, the Front put forward a new conception of the relationship between state and civil society. The heart of its conception of politics was the so-called 'administrative state' (stato amministrativo), in which the state should be neutral and protected from any party ideological influence. The Front's distrust of the world of high politics was thereby directed against the politicisation of public life and can be understood as a reaction to the 'sacralisation of politics' under fascism in which the political affected all spheres of society. ${ }^{30}$ However, it can also be seen as a response to the far-reaching plans for political, societal and moral renewal which were cherished by the Italian resistance. Indeed, the major left-wing political parties and the DC agreed that the post-war Italian state should be obviously distinct from its liberal predecessor and should interfere in the economic and social life of the country. ${ }^{31}$ The Front, by contrast, advocated a state that touched upon the lives of ordinary Italians as little as possible, because, it argued, this would leave room for a vibrant civil society. In the stato amministrativo politicians and civil servants performed their jobs and drew their salary without telling people how to live their lives. ${ }^{32}$ The core of the stato amministratvo was, the Front claimed, that the "Head of State, its ministers, its prime minister, are only delegates to run the administration of the state without any power of initiative'. This 'lack of initiative' implied an

25 Giannini, La folla, I83.

26 Orsina, 'Le virtù liberali del qualunquismo'.

27 Lomartire, Il Qualunquista, 28.

28 'Votate per l'Uomo Qualunque', Fronte dell'Uomo Qualunque, I9 June I946, I. All newspaper articles have been obtained at the Fondazione Ugo Spirito e Renzo di Felice, Archivi della Destra, Rome.

29 'Il programma politica dell'Uomo Qualunque', Fronte dell'Uomo Qualunque, 7 Nov. I945, 2.

30 See, most notably, E. Gentile, Il culto del littorio. La sacralizzazione della politica nell'Italia fascista (Bari: Laterza, 2009).

31 Barbagallo, Dal '43 al '48, I32.

32 Imbriani, Vento del Sud, 54-7I. 
intense dialogue with the electorate, because even 'in the case of foreign invasion' the government was not to decide anything before having consulted the people. ${ }^{33}$ The stato amministrativo should therefore govern without advocating or expressing any moral judgement, and should merely reflect the opinions of the people. Giannini held that 'a country that is not forced to occupy itself with its government is a happy and well-governed country, in which the state administers, performing its natural function, letting citizens enjoy the maximum of civil liberties'. ${ }^{34}$

Thus the Front envisioned a 'neutral state' which refrained from 'deciding what is good and bad' and did not play an active role in ordering social life. ${ }^{35}$ Based on this presumption, the Front also resisted the anti-fascist purges of the CLN government, which were seen as yet another attempt of political elites to impose their political values on the rest of the population. ${ }^{36}$ Viewed from this perspective, there should not even be a justice minister, because this would, for the Front, automatically imply political interference in the judiciary. The Front stated that in the stato amministrativo the branches of the state should function in total 'autonomy' from each other, because 'otherwise we will return to fascism'. ${ }^{37}$ The judiciary's role should be restricted to the protection of civil liberties, which is why the party claimed that every individual citizen should have the opportunity to appeal to the Supreme Court when their rights were jeopardised.

Thirdly, the Front envisioned a political system in which experts rather than professional party politicians administered the country. Politicians should be specialists within their fields of expertise, rather than professional politicians who depended on their parties for a job. The finance minister, for example, should be a banker, whilst the minister of agriculture should have experience in that particular field. ${ }^{38}$ This fit neatly with the Front's ideal of a stato amministrativo in which the state merely ran current affairs and refrained from enacting social change based on any ideological conviction. In contrast to the other political parties, whose politicians were elected on an ideological platform to change the country and emancipate the Italian people, the Front claimed that politicians were 'only delegates to govern' and as such were continuously answerable to the electorate. ${ }^{39}$ What was remarkable for a party so strongly rooted in the south of the country - where support for the monarchy was strong - is that it repeatedly claimed that it did not have a preference for either the monarchy or the republic and as such remained neutral when this question was decided by referendum in June I946. The Front stated that in a stato amministrativo the question whether the Head of State was elected or bequeathed the office was of secondary importance because all state officials were there solely to serve the people.

\footnotetext{
33 'Fisonomia ideologica dell'Uomo Qualunque', Fronte dell'Uomo Qualunque, 3I Oct. I945, 3.

34 Giannini, La folla, i86.

35 'Il paese e lo Stato', Fronte dell'Uomo Qualunque, 3I Oct. I945, I.

36 Giannini was himself an object of the purges and was convicted for having been a fascist journalist, something refuted by historians: see Lomartire, Il Qualunquista, 58.

37 'Il programma politica dell'Uomo Qualunque', Fronte dell'Uomo Qualunque, 7 Nov. I945, I.

38 Non solamente anticomunisti', Fronte dell'Uomo Qualunque, I8 July I945, I.

39 'Si vuole dunque un altro Duce?', Fronte dell'Uomo Qualunque, I3 June I945, I.
} 
In other words, it did not matter 'who governs, but how they govern'. ${ }^{40}$ After the referendum decided in favour of a republic, the Front claimed that people should be allowed to directly elect their head of state and argued that judges should be elected directly by the people. ${ }^{41}$

This rejection of professional politicians and the emphasis on accountability meant that, in essence, the Front held a positive view of the abilities of the common man to make political decisions. ${ }^{42}$ The politicisation of civil society, whether by the fascists or by the moral judgements of the resistance parties, in the Front's view harmed individual liberty. It also impeded political progress, which was only possible thanks to the vitality of a civil society not dominated by ideologically motivated party politicians. The Front therefore advocated a replacement of the system 'of professional politics, a force in which thousands of men are able to live of their profession as a ruler over the people by sacrificing the people', with a system in which 'the honest, peaceful and hard-working people' governed themselves. ${ }^{43}$ This would render the folla 'master of its own destiny', and enable 'progress' in the lives of ordinary citizens. ${ }^{44}$

Giannini thereby contested the idea, broadly shared among the CLN parties, that political parties should be the vanguard in the democratisation of Italian society. ${ }^{45} \mathrm{He}$ instead pointed to the alleged similarities between fascist and anti-fascist politicians in their conception of power and the view they had of ordinary Italians. Giannini stated that "neither intelligence nor culture were persecuted only in Italy and only by fascism. All professional politicians, in every country and in every regime, fear and battle them. The story of the first half of this century is full of struggles of professional politicians against men of intelligence and culture who consider politics with disdain'. 46

These four dimensions of the Front's particular ideology - its rejection of state intervention in economy and society, the emphasis on a 'neutral' state which did not aim to emancipate its citizens, the government of experts rather than ideologically motivated party politicians and the praising of the virtues of the average citizen and the vitality of civil society - set the party apart from virtually all other forces at the time. It negated the distinction purported by the CLN parties between fascism and anti-fascism, by using 'fascism' as a label for any kind of elitist politics it disapproved of, and it claimed that the Front was comprised of 'true anti-fascists' ${ }^{47}$ For the Front, the main challenge for Italy was not the battle against fascism or its legacy. Instead, the political transition was a unique opportunity to 'depoliticise' civil society and

40 'Il programma politica dell'Uomo Qualunque', Fronte dell'Uomo Qualunque, 7 Nov. I945, I.

41 'Discorso Giannini a Bari', Fronte dell'Uomo Qualunque, II June I947, I.

42 See also Orsina, 'Le virtù liberali del qualunquismo', 2 I-22.

43 Giannini, La folla, 58-9.

44 Giannini, La folla, II6, I93.

45 V. Zanone, 'La riduzione qualunqiste del liberalismo', in G. Giannini, La Folla. Seimila anni di lotta contro la tirannide. Con un dibattito su "Liberalismo e qualunquismo" di Giovanni Orsina e Valerio Zanone (Soveria Mannelli: Rubbettino, 2002), 27-38, here 35 .

46 Giannini, La folla, I48.

47 'Le elezioni amministrative', Fronte dell'Uomo Qualunque, 30 Jan. I946, I. 
break the power of political elites. These elites were now no longer represented by the fascist regime, but rather by the political parties of the resistance. Despite this, however, they allegedly still used state institutions to impose their ideology on citizens.

\section{The Front's Challenge to the Nascent Republican Order}

As has been noted above, 'democracy' was the concept par excellence with which post-war Italy had to be politically renovated. It was not only the catchword of the Allied liberators but also the concept behind which the divided resistance could unite in its strife for political and moral renewal. On the one hand, this ensured that these resistance forces had some common ground and a common ideal, namely a democratic Italy. On the other hand, thanks to deep internal divisions, it also ensured that for these forces 'democracy' was essentially the struggle against fascism, which naturally had to be led by the political parties which had led the anti-fascist resistance. As a result, from the perspective of the anti-fascist coalition the Front was necessarily undemocratic because it was in opposition to anti-fascism and to the principle of party democracy. The Front was consequently portrayed as a continuation of fascism. ${ }^{48}$ This raises the question how the Front aimed to establish its own democratic credentials and discredit those of the resistance parties.

Initially, Giannini refrained from labelling the Front 'democratic'. In La Folla he even wrote that 'between democracy and dictatorship there is only a difference in appearance, but in substance they are the same'. ${ }^{49}$ However, thanks to its surging popularity in 1945 and I946, the Front found itself in the midst of a debate between the left and the Christian democrats on the question of who actually were the 'true' democrats that should rebuild Italy. Breaking with the way in which Giannini had referred to democracy during the war, the Front now cleverly made use of the semantic confusion over democracy's meaning and aimed to establish itself as the most democratic force in Italy. The Front rightfully noted that 'nowadays all programmes are democratic', which meant that it was the meaning which was given to democracy which counted. ${ }^{50}$ Because it could and would not, as the resistance parties did, base its democratic legitimacy on anti-fascism, the Front had to be creative in establishing its democratic credentials. The party consequently challenged the democratic legitimacy of its opponents in two ways. First, it claimed that the resistance parties in government flouted the democratic principles with which they claimed to democratise Italy. They actually ruled as a dictatorship. Second, and more fundamentally, the Front claimed that the resistance parties enjoyed a conception of political leadership akin to fascism. Like the fascist regime, the parties behaved like a political vanguard which imposed

\footnotetext{
48 See, for example, A. Moro, 'La politica dell'Uomo qualunque', Sept. I945, in A. Moro, Scritti e discorsi. vol. I (1940-1947) (Rome: Edizione Cinque Lune, I982), 254.

49 Giannini, La folla, I38.

50 'Due democrazie', Fronte dell'Uomo Qualunque, I3 Feb. I946, I.
} 
its values upon a supposedly backward people, although now not led by the single party of fascism, but rather by the multiple parties of the nascent republic.

To start with the former, the Front contended that the political transition led by the CLN parties contradicted the same democratic principles which the resistance forces claimed to promote. The Front accused the CLN party coalition for instance of strengthening its own power position by stripping the Italian king from its powers before the question of monarchy or republic had been decided by the Italian people, and by the passing of an electoral law for the 1946 election which benefited the resistance parties. It also contested several governmental anti-fascist measures, such as the prohibition of supposedly fascist newspapers, linking these to fascism. The Front stated that 'we are not fascists. We have never asked for the suppression of a communist or a Christian democrat newspaper'. ${ }^{51}$ Giannini also disputed the purge of state institutions from fascists from this perspective. The purge (epurazione) was not seen from the perspective of anti-fascism, but from that of the question of the separation of powers, and from this point of view it was allegedly politically motivated and consequently not democratic. ${ }^{52}$ The movement claimed that even the judiciary is antidemocratic'53 and stated that, 'under fascism like under antifascism', magistrates had a political agenda. ${ }^{54}$ Also here the argument surrounding the meaning of 'democracy' was turned against the resistance parties because, although they promoted equality for the law and the freedom of speech in theory, they allegedly failed to uphold these in practice. So in short, the Front stated in 1946 that, for the past two years, the CLN coalition 'has carried out a dictatorship in the name of anti-fascism' ${ }^{55}$ It tried to democratise Italy through 'exceptional laws, the indefinite postponement of elections, limitations on press freedom, persecution of political adversaries, multiplication of special tribunals, abolition of the Senate, a consultative parliament etc., in short: as a factual dictatorship'. ${ }^{56}$

Secondly, the Front contended that the anti-fascist political parties entertained a conception of political leadership akin to fascism. The Front claimed that fascism was not so much 'a political fact' but rather a way of 'conducting politics' which had preceded the March on Rome in 1922 and continued after the fall of Mussolini in 1943. Based on its conception of a stato amministrativo, the Front argued that the new post-war state which the resistance parties constructed was anti-democratic, because it was based upon the leadership of politicians over ordinary citizens. According to the Front, 'the most dangerous legacy of fascism' was the conviction of political elites that the people needed 'school teachers' as leaders because they failed to realise that the people 'is not made up out of children'. Indeed, because the political parties talked about 'giving a political direction' to the country, they became 'directors rather than servants and keep fascism in place, because they keep the moral inferiority of the

\footnotetext{
51 'La maggioranza degli innocenti', Fronte dell'Uomo Qualunque, II Dec. I946, I.

52 'Ma dove sono queste destre?', Fronte dell'Uomo Qualunque, 5 Dec. I945, I.

53 'Anche la giustizia è antidemocratica', Fronte dell'Uomo Qualunque, 22 Jan. I947, I.

54 'Il programma politica dell'Uomo Qualunque', Fronte dell'Uomo Qualunque, 7 Nov. I945, I.

55 'La nuova legge elettorale è un'offesa alla democrazia', Fronte dell'Uomo Qualunque, I3 Mar. I946, 3.

56 'Due Democrazie', Fronte dell'Uomo Qualunque, I3 Feb. I946, I.
} 
people intact . . they believe that without a Duce there is no progress' ${ }^{57}$ The Front pointed to the alleged similarities between the conception of leadership of fascism and that of the resistance parties because they were allegedly both grounded upon the leadership of a political elite over a citizenry which needed emancipation. This casted doubt over their democratic credentials, because 'we should not leave the direction of political life to a restricted aristocracy: we want to impede that a restricted category of men has the monopoly over the direction of the political life of the country, even at the risk of making errors and painful experiments' ${ }^{58}$

By shrewdly using the broad range of possible connotations of the term 'democracy', the Front challenged the democratic credentials of the anti-fascist coalition. It simply attacked the party coalition with its own ideals of political equality, freedom of speech and an independent judiciary. The Front claimed that (s)he "who patiently examines the measures and actions taken from the liberation until today by the governments of the CLN, sees that ... freedom for these parties serves to [realise] ends antithetical to true democracy'. ${ }^{59}$ But it also did so by aiming to establish itself as a, or even, the democratic force of the country. The Front claimed itself to be the only party to endorse a 'democracy without adjectives' - neither Christian nor Marxist and as such claimed to be the party of the 'true democrats of the Italian people'. ${ }^{60}$ Seen from this perspective, the anti-fascist government was yet another political elite that told ordinary Italians how to live their lives and, in this way, was yet another form of domination after two decades of dictatorship. Because the democracy 'with adjectives' implied political domination and the politicisation of civil society, the Front argued that it was now time to try a democracy without adjectives so that the 'suppression of 45 million Italians' by the political class would finally stop. ${ }^{61}$

As noted at the outset of this article, the Front's political ideology appealed to over two million voters in the 1946 elections, but the party failed to make headway in the parliamentary elections two years later. The Front's advance was thwarted by the coming of the Cold War. The mounting tensions between the Marxist left and the DC culminated in the expulsion of the left-wing parties from government in May I947. The DC successfully established itself as the party of individual freedoms and, also thanks to support from the Vatican and the United States, made it increasingly difficult for other parties to challenge its hegemony as bulwark of anti-communism. ${ }^{62}$ The period which had started with a war between fascism and anti-fascism 'closed with a religious war between communism and anti-communism'. ${ }^{63}$ It meant that the anti-fascist divide in politics was replaced by anti-communism, at least in the I950s,

\footnotetext{
57 'Si vuole dunque un altro Duce?', Fronte dell'Uomo Qualunque, I3 June I945, I.

58 'Per il risalto d'Italia e la libertà d'Europa', Fronte dell'Uomo Qualunque, 25 June 1947, 3.

59 'La nuova legge elettorale è un'offesa alla democrazia', Fronte dell'Uomo Qualunque, I3 Mar. I946, 3.

60 'Due milioni di voti per l'Uomo Qualunque', Fronte dell'Uomo Qualunque, 26 June I946, I.

61 'Non solamente anticomunisti', Fronte dell'Uomo Qualunque, I8 July I945, I.

62 S. Tramontin, 'La Democrazia cristiana dalla Resistenza alla Repubblica', in Malgeri, ed., Storia della Democrazia Cristiana. vol. 1, I3-177, here I25; Ventresca, From Fascism to Democracy.

63 Barbagallo, Dal'43 al '48, I49.
} 
the iciest phase of the Cold War, which entailed that anti-fascism in these years lost its immediate political relevance. ${ }^{64}$

This meant the end of the electoral success for the Front. ${ }^{65}$ Whereas it had at first creatively challenged the dichotomy between fascism and anti-fascism, the change from anti-fascism to anti-communism forced the Front to take sides in the changed political environment and it naturally ended up in the anti-communist camp. Whereas the party had previously claimed that it 'preferred' the communists to the 'political class of Rome', ${ }^{66}$ the Front now supported De Gasperi's ditching of the Marxist left from the anti-fascist government of national unity. Giannini even claimed that 'I like this government [without the left] very much and 'I like De Gasperi very much', based on the DC's position as bulwark against communism. ${ }^{67}$ The Front's distinctive anti-elitist and anti-anti-fascist discourse was overruled by the domestic reflection of the global conflict between communism and anti-communism. ${ }^{68}$ The party performed poorly in the I948 general election and dissolved mainly into the Liberal Party afterwards.

\section{The Impact of the Front on Republican Italy}

Even if 'as a party' the Front failed to establish itself in the quickly changing political climate of the late I94Os, its political legacy was long-lasting and its ideology made a deep impact on Italy's republican history. Its ideology therefore merits historical study which goes beyond the party's electoral performance and constituency in the immediate aftermath of the war. The particular way in which the movement claimed democratic credentials has two implications.

The first implication of this article concerns the importance of the Front's ideology as an example for the historical study of democracy in post-war Europe. If we follow Jan-Werner Müller's interpretation of post-war democracies as 'limited democracies' in which political elites were guided by a 'distrust of popular sovereignty', ${ }^{69}$ a study of competing understandings of democracy expressed in the aftermath of the war which contrasted this elitist conception of politics are instrumental to a more accurate history of post-war democracy as the continuous struggle between various democratic paradigms. ${ }^{70}$ Political movements such as the Front challenge historians to be open to alternative conceptions of democracy which in turn unveil how key features of

64 A. Giovagnoli, Il partito Italiano. La Democrazia Cristiana da 1942 a 1994 (Bari: Laterza, I996), 56.

65 Lomartire, Il Qualunquista, I78.

66 'Il paese e lo Stato', Fronte dell'Uomo Qualunque, 3I Oct. I945, I.

67 'Un grande discorso di Giannini all'Assemblea Costituente', Fronte dell'Uomo Qualunque, 24 Dec. I947, I.

68 Capozzi, 'La polemica antipartitocratica', I8 I.

${ }^{69}$ J. W. Müller, Contesting Democracy. Political Thought in Twentieth Century Europe (New Haven: Yale University Press, 20II), I28, 24I.

${ }^{70}$ Aided by the fact that virtually all contemporary political actors play on the discourse of democracy. See, J. W. Müller, 'European Intellectual History as Contemporary History', Journal of Contemporary History, 46, 3 (20II), 574-90. 
this post-war model of democracy were contested from the outset. Indeed, as Martin Conway has argued, modern European politics is 'a struggle between competing models of democracy, including ideologies of the left and the right that one might not automatically associate now with the term democracy' ${ }^{71}$ This study of the historical dimension of disputes on the meaning of democracy remains especially important at a time when political parties which claim to be democratic, but which simultaneously question the anti-fascist consensus, gained political prominence across Europe. $^{72}$

In the light of this development it is tempting to see the Front as a pioneering populist party foreshadowing the rise of European populism after the fall of the Berlin Wall. ${ }^{73}$ Indeed, the Front's glorification of the 'person in the street' and the rejection of professional politicians could be considered key elements of contemporary populism. ${ }^{74}$ If populism is seen as 'government by the sovereign people, not as government by politicians', ${ }^{75}$ or 'as popular democracy without parties' ${ }^{76}$ the party certainly fits these descriptions. Yet, even though the Front certainly relates to populism, this relationship is complex. In contrast to many populist parties, the Front did not embrace nationalism. ${ }^{77}$ Giannini even stated that 'there is no idea more flawed [than the patria], and if there is anything mortal on this earth, the idea of the patria is the most mortal of all'. ${ }^{78}$ The Front also harboured a strong liberal current and held that political progress could only occur if the independence of civil society was respected. ${ }^{79}$ In contrast to the plebiscitary conceptions of democracy found among many populist parties, according to which the volonté general should be omnipotent, the Front endorsed judicial autonomy - and a government by experts - which should be answerable to the people, but not formed by the people.

The relationship between the Front and contemporary populism is therefore not straightforward because it touches upon a very specific Italian characteristic of the dichotomy between 'elite' and the 'people', which leads to the second implication of this article. The historical relevance of the Front lies in its critique on the construction

71 M. Conway, 'The Rise and Fall of Europe's Democratic Age I945-I973', Contemporary European History, I3, I (2004), 67-88, here 88.

${ }^{72}$ For the demise of the anti-fascist consensus and its relationship with the challenging of the principles of postwar democracy, see D. Stone, Goodbye to All that? A Story of Europe Since 1945 (Oxford: Oxford University Press, 20I4), esp. ch. 7, 8, and the conclusion.

73 See in particular the essay of P. Deotto and L. Garibaldi, La vera storia dell'Uomo Qualunque (Chieti: Salfonelli, 20I3). See also M. Tarchi, L'Italia populista. Da qualunquismo ai girotondi (Bologna: Il Mulino, 2003); C. Ruzza and S. Fella, Re-inventing the Italian Right: Territorial Politics, Populism and 'Post-Fascism' (London: Routledge, 2009), I3.

74 Mudde, Populist Radical Right Parties in Europe (Cambridge: Cambridge University Press, 2007); P. Taggart, Populism (Philadelphia: Open University Press, 2000o).

${ }^{75}$ M. Canovan, 'Taking Politics to the People: Populism as the Ideology of Democracy', in Y. Mény and Y. Surel, eds., Democracies and the Populist Challenge (Basingstoke: Palgrave McMillan, 2002), 25-44, here 33 .

76 P. Mair, 'Populist Democracy vs Party Democracy', in Mény and Surel, eds., Democracies and the Populist Challenge, 8I-98, here 9I.

77 Orsina, 'Le virtù liberali del qualunquismo', 2 I .

78 Giannini, La folla, 92.

79 Orsina, 'Le virtù liberali del qualunquismo', I4. 
of the 'republic of the parties' in post-war Italy. The Italian post-war constitution of 1948 was the result of the strained, but collaborative efforts of the socialists, communists and Christian democrats. It expressed the centrality of the parties in the new Italian state and presumed their leadership in the emancipation of Italian citizens. ${ }^{80}$ The Front argued that this system, in which the relationship between state and society was 'managed', not to say dominated, by political parties, was essentially akin to the fascist era, in which the fascist party played this role. Indeed, Giannini claimed that 'both the single party of the dictatorship, and the various parties of democracy, have the monopoly on politics in the country, in which they constitute a minority, and they propose programmes that the country has to vote on in a democracy, accept without discussion in a totalitarian regime'. ${ }^{81}$

Whereas this view was denounced as pseudo-fascist at the time, it has recently emerged as an explanation for Italy's continuing political difficulties since the early I990s. This perception of continuity between fascism and the republican order followed a speech in 1993 by then-prime minister Giugliano Amato, who pointed to the way in which political parties persistently had used state institutions to establish popular support in society between the I920s and I990s. Indeed, to describe the tumultuous events of the early I990s, the socialist Amato talked about 'an authentic regime change, leading after seventy years to the death of this party-State model, introduced in Italy by fascism and inherited by the Republic, solely transforming the singular into plural'. He thereby explicitly underscored the similarities between the fascist and republican political order when it came to the way in which parties monopolised the relationship between state and citizens. ${ }^{82}$

Seen from this perspective, the Front actually pioneered this interpretation of the similarities between the way in which fascism and the republican parties had defined the relationship between state and society. The Front was indeed the first in a long chain of political resistance against the 'republic of the parties' in post-war Italy. ${ }^{83}$ However, even though the dominance of political parties was questioned from various sides, ranging from the neo-fascist Italian Social Movement (Movimento Sociale Italiano) to centrist intellectuals and advocates of the values of pre-fascist Italy, ${ }^{84}$ it never found a structural political outlet. Thanks to the dominant assertion of antifascist values, particularly since the establishment of the centre-left coalition in the I960s, ${ }^{85}$ any critique of, or alternative to, the functioning of Italian democracy was quickly delegitimised as right-wing and at odds with the values of democracy as

${ }^{80}$ Barbagallo, Dal '43 al '48, I38; Piretti, 'Continuità e rottura alla nascita del sistema dei partiti'.

81 Giannini, La Folla, I38.

${ }^{82}$ Quoted by Lupo, Partito e antipartito, I5. My emphasis. See also G. Crainz, Il paese reale. Dall'assassino di Moro all'Italia di oggi (Rome: Donizelli editore, 20I2), 295-6; Orsina, Il berlusconismo, 60-I.

83 Lupo, Partito e antipartito, 7; Capozzi, 'La polemica antipartitocratica', I80-I.

${ }^{84}$ R. Chiarini, 'La fortuna del gollismo in Italia. Le suggestioni di una "Seconda Repubblica", Storia Contemporanea, 22, 3 (I992), I73-220, esp. I90-I; Capozzi, 'La polemica antipartitocratica'.

85 On the coalition between Christian democrats and the socialist party, see L. P. Remaggi, La democrazia divisa. Cultura e politica della sinistra democratica dal dopoguerra alle origine del centro-sinistra (Milan: Edizioni Unicolpi, 20II), 205-; Orsina, Il berlusconimo, 69-74. 
such. ${ }^{86}$ At the same time, the fact that Italy harboured the strongest communist party of the West ensured that voters dissatisfied with the state of democracy still voted for the Christian democrats as the only bulwark against communism. One could therefore argue that the Front's ideology was still there, but it was repressed by the dual forces of anti-fascism and anti-communism in operation in Italy from the late I940s onwards.

However, all this changed in the early I990s when both anti-fascism and anticommunism lost some of their force in conjunction with the fall of the so-called First Republic. It stretches beyond the scope of this article to describe the tumultuous events of I992-I994 in any detail. It is important to state, however, that the country experienced an exceptional political crisis in which the system which centred on the political parties which had founded the republic broke down. The old parties largely imploded or underwent ideological transformation, the electoral system was adapted and a substantial part of the political class came under judicial investigation. ${ }^{87}$ This created room for the expression of anti-anti-fascist values and the rejection of party politics, which in turn revealed the resilience of the Front's ideology. From this perspective, as has recently been argued by the Italian scholar Giovanni Orsina, the clearest connection between the Front and the rejection of this conceptualisation of the relationship between state, parties and society lies arguably in the figure of Silvio Berlusconi and his political movement Go Italy (Forza Italia). ${ }^{8}$ Like Giannini, Berlusconi has not acted as a typical right-wing populist with a strong nationalist rhetoric but instead has united liberal and populist elements in his political discourse, questioned the anti-fascist-fascist divide and argued in favour of reducing the influence of the parties and state on civil society. Most notably, his persistent electoral success, Orsina argued, should not be seen solely as the political response to broadly shared anti-party sentiments among the Italian population, but rather as a sign of popular resistance to the paternalistic, or 'pedagogic', way in which parties have aimed to 'emancipate' ordinary citizens. Berlusconi's success therefore also relates to the persistent popular resentment against political elites which found no electoral outlet, but remained an underlying current of Italian politics.

Some fifty years before the crisis of the I990s, the Front posed a similar challenge to the way in which political elites conceived of their relationship with citizens at a moment of political transition. It claimed to liberate civil society from the domination

86 R. Chiarini, 'La fortuna del gollismo in Italia. L'attacco della destra alla "Repubblica dei partiti", Storia Contemporanea, 22, 3 (I992), 385-424, esp. 385-8; G. Orsina, 'Il cavaliere, la destra e il popolo', in G. Orsina, ed., Storia delle destra nell'Italia repubblicana (Soveria Mannelli: Rubbettino, 2009), 257-285, here 263 .

${ }^{87}$ For an historical overview, see P. Grillo di Cortona, Dalla Prima alla Seconda Repubblica. Il cambiamento politico in Italia (Rome: Carocci editore, 2007). For an analysis of the institutional effects, see S. Z. Koff and S. P. Koff, Italy from First to Second Republic (London: Routledge, 200o). For a historiographical overview of these efforts to re-evaluate Italian history since the early I990s, see M. Lazar, 'Testing Italian democracy', Comparative European Politics, II, 3 (2013), 3I7-36; M. Ridolfi and A. Roche, 'L'historiographie politique de l'Italie républicaine', Vingtième Siècle. Revue d'histoire, Ioo (2008), II20.

88 See, most notably, Orsina, Il Berlusconismo nella storia d'Italia, ch. 2-3. 
by the Italian parties and the state. The Front's most distinctive characteristics were its juxtaposition between political elites and the benign folla, its call for a de-politicisation of society and its perception of the similarities between fascist and republicandemocratic political parties, particularly in the way they saw the political party as the exclusive means to manage the relationship between state and citizen. Through opposing party democracy and anti-fascist values the Front vocally expressed an underlying current of Italian history which made itself heard in key moments of political transition, such as in the aftermath of the war and during the political crisis of the I990s. 